\title{
The Structures and Functions of the Imperative Constructions in Dickens' Hard Times
}

\author{
Hana'a Abass Suleiman \\ Department of English, Faculty of Arts, University of Anbar, Iraq \\ hanaahanaa133@gmail.com
}

\begin{abstract}
:
This paper intends to shed light on the different forms and functions of the imperative sentences in the novel of Hard Times. This novel is found to fulfill the purpose of the study. One of its most distinctive features is the excessive use of imperative structures. The results show that imperatives are commonly used by the characters of the novel. This study aims to analyze the imperative utterances in the novel and to show their forms and functions according to Alexander Model 1997 which is adopted to achieve the purpose of the study. The frequency and percentage of every type of the imperative used in the novel are given in specific tables to show how many times each form is used more than the other which would reveal Dickens's intention to express advice, suggestion, request, etc. The data collected from the corpus of Hard Times' text. The study limits itself to analyze the imperative structures and shows the functions according to Alexander Model. It is hoped that this study will be valuable for those who study English as a foreign language and those also who are interested in English linguistics.
\end{abstract}

Keywords: $\quad$ Imperative Constructions; Frequency; Uses; Structures.

Crossref doi https://doi.org/10.51345/.v31i2.322.g184 


\section{Introduction}

Hard Times is written by Charles Dickens. The novel Hard Times dramatizes the life in the Victorian Age when the Industrial Revolution was emerged. It tells the sufferings of the Working-class people who were oppressed by the High-class people. As it tackles all the social problems, sufferings and bad behaviors practiced by the community of England upon emerging the Industrial Revolution which impacted on the English people in the sense that new concepts were appeared like the Utilitarianism and Paradoxical Age. However, it is clear that Dickens used the language more effectively but especially by the language used among the characters of the novel. For that reason, an interest in studying the language of the novel is aroused, and one aspect of studying the language is the study of the imperative utterance there.

This paper deals with the imperatives from two perspectives, form and function. It is hypothesized that the use of the imperatives in a novel or in any other type of utterances one should rely more on pragmatics than on syntactic or semantic approaches. Many of the utterances do not reflect their related moods, but different illocutionary forces. What matters is the intended functions of these utterances not their explicit forms.

Analyzing the whole imperative utterances of Hard Times from these two perspectives, it is noticed that the function of many of the imperative utterances are not commands or orders, but they communicate various other functions. In addition, there is the variance between the form and the function of some of the utterances. The main aim of this paper is to show the importance of depending on pragmatics in analyzing texts as novels. Analyzing from syntactic and semantic perspectives will not be sufficient in reflecting the real intended functions of the used imperatives. So it is believed that a pragmatic analysis will be a significant one to complete an analysis of any discourse.

\section{Imperative Review}

Imperative can be defined in different ways by many grammarians. Crystal (1991: 171-172) states that this term is used in the grammatical classification of sentence types, and usually seen in contrast to indicative, interrogative, etc. He (2004: 227) remarks that an imperative usage refers to verb forms or sentence clause types typically used in the expressions of command, e.g. Go away. Formally, imperative clauses as Biber et al (1999:219) comment are characterized by the lack of a subject, the use of the base form of the verb and the absence of modals as well as tense and aspect markers as in:

\section{1- Get off the table.}

\section{2- Don't forget about the deposit.}

Biber et al (ibid) give the reason that an imperative typically urges the addressee to do something (or not to do something) after the moment of speaking; hence there is no need for tense, aspect or modal specification. From a different perspective, Quirk, et al (1985: 827) view imperative as a type of sentence that lacks the grammatical subject and their verbs have the base forms, for example, Give me a digital watch for my birthday. 
As for Swan (2016:224) he thinks that affirmative imperatives have the same form as the infinitive without to; negative imperatives are constructed with do not, (don't)+infinitive. He also comments that in sentences like, Come here, Be quiet, Have a drink, or Don't worry about it, those verb forms as come, be, have and don't worry are called "imperatives". Buscemi et al (2004: 466) state that the imperative mood communicates a command or a request, as in:

\section{3- "Stop!" ordered by the police officer. \\ 4- "Please return all the books promptly."}

They give a note that in the sentences using the imperative, the subject you is understood. When an imperative sentence gives an order, makes a request or provides instruction, typically an exclamation mark is used (!). Otherwise a period (.) is used to end an imperative sentence. (WWW.E:/internet files /imperative sentence.definition and examples of imperative sentences in English, mht).

\section{5- Get out of the way! \\ 6- Please pass the mustard. \\ 7- Turn right at the stop light, and drive up the hill.}

Takuhashi (2004: 41-43) states that there are three controversial features of the imperatives that can be explained as, hypothetical, non- past and second person. He assumes that imperative is hypothetical in the sense that it needs a speaker presenting of a possible situation to the addressees. While the non- past seems well- established that the imperative either refers to the present or to the future so it doesn't refer to a past situation, e.g. Talk with your doctor now/tomorrow.

So the speaker wants from the addressee doing something either in the moment of speaking (present) or later on (future). The third feature which is the second person pronoun appears where the imperative is interpreted as being directed at non- individual addressee, e.g. You/You guys stand up!

\section{The structures and Functions of Imperative Constructions}

Richard and Schmidt (2010: 237) define form- function relation as; the relationship between the physical characteristics of a thing (its form) and its role or (its function). This distinction is often referred to studying language use, because a linguistic form (the imperative) can perform a variety of different functions as the table illustrates:

\begin{tabular}{|l|l|}
\hline Imperative forms & Communication functions \\
\hline 1.Come round for as drink. & Invitation \\
2.Watch out & Warning \\
3.Turn left at the corner & Direction \\
4.Pass the sugar & Request \\
\hline
\end{tabular}

Table (1) Communicative Functions of imperative 
Praninkas (1975: 250- 256) discusses some forms of imperative used to express certain functions, for example, direction and instruction when the sentence type has no overt subject and the verb is in the verb phrase form, e.g. Put off seeing an optometrist.

The best way of negating verbs is by adding (don't, do not) or adding the frequency word 'never' can make the verb phrase in the form of negative, e.g.

\section{8- Don't put off seeing optometrist.}

\section{9- Never neglect your eyes,}

By adding the polite expression 'please' we can make a request. It comes at the beginning or at the end of an imperative sentence but it never comes between the verb and its subject. For example,

\section{0- Please get here on time.}

While the function of suggestion can be achieved by using 'let' structure when the addressers include the speaker. This construction 'let' can be usually used instead of the complete form 'let us', a verb should follow ' let's' structure, as in:

\section{1-Let's go to school. (ibid)}

Radford (2004: 196) explains the possibility in which the imperative structure can take post verbal subject when the verb is transitive, as in:

\section{2-Leave you now!}

\section{3-Read you that book!}

The first sentence is grammatically acceptable, while the second one isn't because the verb is transitive. On the other hand, Eastwood (2016: 14-17) states that imperative takes three essential forms which are; positive imperative when the verb is in the base form, negative imperative by adding 'don' $t$ ' or 'do not' and emphasis when the persuasive 'do' is inserted, as in:

\section{4-Come here!}

\section{5-Don't remove this book from the library.}

\section{6 -Do be careful!}

Biber et al (1999:219) indicate that the addressee in imperative clauses is sometimes specified in the form of a subject or more commonly as a vocative as in:

\section{7-You go home and go to sleep}

18-Don't you dare talk to me like that clear, I've had enough. 19-Melissa, take those things away. 
The imperative, e.g. Wait here, might be addressed to one person or several persons (Alexander (1997:185) states that you is added to get the attention of the person. However, Alexander (ibid: 185186) shows the following ways used in an imperative to attract the attention of a person or of the people spoken to:

1- You + imperative

20-You wait here for a moment.

Intonation or stress is important here to clarify the meaning

2- You or names(s) + you:

21-You wait here, Jim and Mary, you wait here.

3- Imperative + name or name + imperative:

22-Drink up your milk, Sally! Or Sally, drink up your milk!

4- Imperative + reflexive

23-Enjoy yourself.

5- Everybody, somebody with imperative:

24-Everybody keep quiet! Keep still everybody!

Regarding the form of imperative, Swan (2005:306-307) states that Let is followed by an infinitive without to:

Let is followed by an object + infinitive without to.

25-We usually let the children stay up late on Saturdays.

Let is not used in passive forms: allow is preferred.

26-After questioning, he was allowed to go home.

With object+ preposition /adverb particle

Let can be followed by an object and a preposition phrase or adverb particle expressing movement.

27-You'd better let the door out of the car.

Murphy \& Smalzer (2002:74) indicate that let's not is the negative of let, as in:

28-It's cold. Let's not go out. Let's stay home.

Swan (1995:87) adds another form for imperative he states that parents often use the structure $b e+$ infinitive to give orders when speaking to children.

\section{9-You are to do your homework before you watch $T V$.}

Eastwood (2016:14-17) mentions that by depending on situation the form of imperative is used whether it is an order, request or suggestion. It is preferred to use a polite formula such as 'could you' rather than imperative to avoid making the imperative rude and putting the request in the form of question to make it politer, as in:

30-Can you get out your books, please? 
Polite formula is not used by common people only but it can be used by those in position or authority. Order is a function of imperative which can be used in some cases:

A. Teacher to students. E.g. open your book at page sixty.

B. Doctor to patient. E.g. just keep still a moment.

C. Boss to employee. E.g. Don't spend too long on this traffic sign.

It can also be used between equals in informal way, as in :

\section{1-Hurry up, or we're going to be late.}

Mey (1993:48) states that "linguistic functions of use are best studied in situations where people interact normally, using language face to face". He adds (ibid: 73) that how close the person is and how much the social distance is between the interlocutors are decisive points in using 'bald' imperatives. Imperatives for example are not usually used to give orders or requests in English (Searle, 1975 cited in Levinson, 1983:264-7). A long list could be constructed of the ways of indirectly requesting an addressee to shut the door:

\section{2- I want you to close the door.}

Can you close the door?

Would you close the door?

Would you mind closing the door?

You ought to close the door.

May I ask you to close the door?

Did you forget the door?

From the above mentioned examples, it is noticed that not any one of them are forms of imperatives, but nevertheless all of them are used as requests to close the door. That is to say, that all of them are asking the addressee to do an act for the speaker, and this is what defines the imperative utterance. Searle (1969:66) proposes a set of felicity conditions for describing the orders. He remarks that orders have:

1. Propositional content: The speaker predicates a future act of the hearer.

2. Preparatory condition:

a. The hearer is able to do the action.

$b$. The speaker believes that the hearer is able to do the action.

c. The speaker in a position of authority over the hearer.

3. Sincerity: The speaker wants the hearer to do it.

4. Essential: The utterance counts as an attempt to get the hearer to do the action in virtue of the speaker's authority.

What is meant by an imperative sentence is best be viewed by what its function is, and that depends on its use in context and to look for the intended meaning of the speaker. To understand the sentence from a pragmatic perspective. Searle states (1979: 13) that imperatives and interrogatives 
perform directive speech acts which are "attempts to get the hearer to do something". The propositional content of these acts represents a future action of the hearer. Imperatives are requests for action, while interrogatives are requests for information. That is why there are cases of inquiring that are considered as imperatives since we want from the hearer to do the act of informing us about something.

Bach and Harnish (1979:47) classify the imperatives into six types:

1. Requisites: (ask, beg, invite, request, supplicate)

2. Requirements:(command, order, instruct)

3. Permissives: (allow, permit, pardon)

4. Advisories: (advise, recommend, warn, suggest)

5. Questions: (ask, require)

6. Prohibitive: (prohibit, forbid)

Another list of the imperative functions is made by Alexander (1997:185) . They are:

a- Orders and Requests:

33-Clean the room.

Please, clean the room.

b- Warning

34-Stop talking. They will hear you.

c- Directions

35-Turn left then drive straight forward.

d- Instructions

36-Click on the program icon

e- Prohibitions and Public Notices

37-Don't smoke here.

f- Advice

38-Go home if you feel sick.

g- Invitations

39-Come tomorrow and meet my new friends.

h- Offers

40-Have a drink.

i-Expressing Rudeness

41-Shut up.

Quirk et al. (1985:831) show many functions which almost depend on the situational context:

1.Order and command.

2.Prohibition.

3.Request.

4.Please.

5.Advice, recommendation.
42 -Make your bed at once.

43 - Don't touch.

44-Shut the doors, please.

45 -Help.

46 -Take an aspirin for your headache. 


\section{7-Lock the door before you go to bed.}

6.Warning. $\quad 48$-Be careful!

7.Suggestion. 49 -Let's have a party.

8.Instruction. $\quad \mathbf{5 0}$-Take the first street on the left.

9.Invitation. 51 -Make yourself at home.

10.Offer. 52 - Have a cigarette.

11.Granting permission. $\quad 53$-Help yourself.

12.Good wishes. 54 -Have a good time.

13.Imprecation. 55 -Go to hell!

14.Incredulous rejection. $\quad 56$-Let me see now.

\section{Overview of Dickens' Hard Times style}

The novel of Hard Times dramatizes the life in the Victorian Age when the Industrial Revolution was emerged. It tells the sufferings of the Working-class people who were oppressed by the High-class people. As it tackles all the social problems, sufferings and bad behaviors practiced by the community of England upon emerging the Industrial Revolution which influenced on the English people in the sense that new concepts were appeared like the Utilitarianism and Paradoxical Age. However, it is clear that Dickens used the language more effectively. He adopted a remarkable style through he used the language to achieve his purposes, it was an individual quality that was proved by Wales (1989: 1) who ensured that "style is the man himself".

This paper deals with the imperatives from two perspectives, form and function. What matters is the intended functions of these utterances not their explicit forms. Analyzing the whole imperative utterances of Hard Times from these two perspectives, it is noticed that the function of many of the imperative utterances are not commands or orders, but they communicate various other functions

\section{Aims of the Study}

This study aims to examine the number of the imperative sentences that are used in Dickens Hard times to achieve the following points:

1- To classify the imperative sentences into types and functions in order to show the frequency and rate of each type and function that help to determine which type is frequently used than other types. 
2- To draw a comparison between the imperative sentences used in the text and the types which are set in Alexander's model (1997).

3- To verify the odd and irregular word order of certain imperative structures used in the novel.

\section{Methodology}

It is considered the practical part of any research in which the collected data are analyzed. This section includes three basic subsections which are; the first one is the data collection in which the number of imperative sentences from the text of the novel. The second section deals with the analysis of the data and the third one shows the results and discussions.

\section{Data Collection}

The approach used in collecting the data is quantitative. It is done by reading the whole text of the novel and extracting all the imperative sentences. To fulfill the objectives of the study about the imperative sentences which are collected from the edited version of the text Hard Times then giving the rates of the imperative constructions.

\section{Data Analysis}

The approach that is used to analyze the data depends on examining the number of imperatives in the novel of Hard Times and show their different forms and functions. These sentences are taken to be analyzed. The results are tabulated and these tables consist of the frequency along with the percentage of the forms and functions of imperative sentences. The results will help the readers to determine which type is most used. Tables number (2) and (3) consist of the frequency and the percentage of every form of imperative used in the text. In Diagram (4), the functions of the imperatives are illustrated. They have been determined by depending on their contexts. The functions of many examples of the imperative utterances taken from 'Hard Times' are mentioned to show that imperatives do not reflect orders or commands only but many different functions that are influenced to a great degree by the context. Some of the functions proposed by Bach and Harnish (1979), Leech (1983) and Alexander (1997) are selected to be applied in analyzing the data collected from the novel.

\section{7-1. Analysis of the Imperative structure}

The analysis of the imperative form structure will be according to Alexander's model which is composed of:

1-The base of $v$.

2-Phrasal verb

3-Don't + base

4-Addressing somebody (vocative)

5-(Let) structures

6-Imperative+ tag questions 
The following table shows the frequency of every form and its percentage to the whole number of the imperatives used in the novel.

Table (2): The Frequency of the Forms of the Imperative Structures

\begin{tabular}{|l|l|l|}
\hline \multicolumn{1}{|c|}{$\begin{array}{c}\text { Forms of the } \\
\text { imperative structures }\end{array}$} & \multicolumn{1}{c|}{ Frequency } & \multicolumn{1}{c|}{ Percentage } \\
\hline Base (v.) & 143 & $42.058 \%$ \\
\hline Vocative(Addressing someone) & 73 & $21.470 \%$ \\
\hline Let & 50 & $14.705 \%$ \\
\hline Phrasal (v.) & 39 & $11.47 \%$ \\
\hline Don't + base & 35 & $10.29 \%$ \\
\hline $\begin{array}{l}\text { Imperative } \\
\text { + tag question }\end{array}$ & 0 & 0 \\
\hline
\end{tabular}

The base form of the verb represents a high percentage in the corpus. They form $42.058 \%$ of the whole used imperative utterances such as the verbs, give, look, come, stop. The subject is usually omitted, but understood from the context to refer to the addressee. Also this novel shows a high percentage of the use of phrasal verbs than other structures of imperatives. They form $11.47 \%$ especially activity verbs such as jump up, come in, look at, get out. They are commonly used by the characters of the novel.

Table (3): The Frequency of the Forms of the Imperatives in Data

\begin{tabular}{|c|c|c|c|c|c|c|c|c|c|c|c|}
\hline $\begin{array}{l}\text { The } \\
\text { base V } \\
143\end{array}$ & $\begin{array}{l}\text { Rate } \\
42.05 \\
8 \%\end{array}$ & $\begin{array}{l}\text { Phrasa } \\
\text { l } 239 \\
\text { V } 39\end{array}$ & $\begin{array}{l}\text { Rate } \\
11.47 \\
\%\end{array}$ & $\begin{array}{l}\text { Don't } \\
\text { +base } \\
\text { V } 35\end{array}$ & $\begin{array}{l}\text { Rate } \\
10.29 \\
\%\end{array}$ & Let 50 & $\begin{array}{l}\text { Rate } \\
14.70 \\
5 \%\end{array}$ & Vocative 73 & $\begin{array}{l}\text { Rate } \\
21.47 \\
0 \%\end{array}$ & $\begin{array}{l}\text { Impe } \\
\text { rativ } \\
\text { e+ } \\
\text { tag } \\
\text { quest } \\
\text { ion }\end{array}$ & $\begin{array}{l}\text { Rat } \\
\text { e } \\
\text { 0 }\end{array}$ \\
\hline Call & & $\begin{array}{l}\text { Go } \\
\text { along }\end{array}$ & & $\begin{array}{l}\text { Don't } \\
\text { call }\end{array}$ & & Let me & & $\begin{array}{l}\text { Say, good } \\
\text { M'choakumc } \\
\text { hild }\end{array}$ & & & \\
\hline Tell 15 & & $\begin{array}{l}\text { Walk } \\
\text { in }\end{array}$ & & $\begin{array}{l}\text { Don't } \\
\text { tell us }\end{array}$ & & Let me & & $\begin{array}{l}\text { Pray, Mrs. } \\
\text { Gradgrind }\end{array}$ & & & \\
\hline Describe & & Put in & & $\begin{array}{l}\text { Don't } \\
\text { tell me }\end{array}$ & & Let us & & Please, sir & & & \\
\hline Give 9 & & $\begin{array}{l}\text { Let } \\
\text { down }\end{array}$ & & $\begin{array}{l}\text { Don't } \\
\text { give }\end{array}$ & & $\begin{array}{l}\text { Let us } \\
\text { strike }\end{array}$ & & $\begin{array}{l}\text { Bitzer, turn } \\
\text { you }\end{array}$ & & & \\
\hline $\begin{array}{l}\text { Suppose } \\
3\end{array}$ & & Get out & & $\begin{array}{l}\text { Don't } \\
\text { say }\end{array}$ & & $\begin{array}{l}\text { Let me } \\
\text { hear }\end{array}$ & & $\begin{array}{l}\text { Take } \\
\text { yourself }\end{array}$ & & & \\
\hline Forbid & & Get out & & $\begin{array}{l}\text { Don't } \\
\text { be }\end{array}$ & & $\begin{array}{l}\text { Let me } \\
\text { have }\end{array}$ & & $\begin{array}{l}\text { Jupe, stay } \\
\text { here }\end{array}$ & & & \\
\hline Dumb & & Let in & & $\begin{array}{l}\text { Don't } \\
\text { be }\end{array}$ & & $\begin{array}{l}\text { Let the } \\
\text { girl }\end{array}$ & & $\begin{array}{ll}\text { Girl. } & \text { Take } \\
\text { this } & \end{array}$ & & & \\
\hline
\end{tabular}


Website : www.uoajournal.com

E-mail : info@uoajournal.com

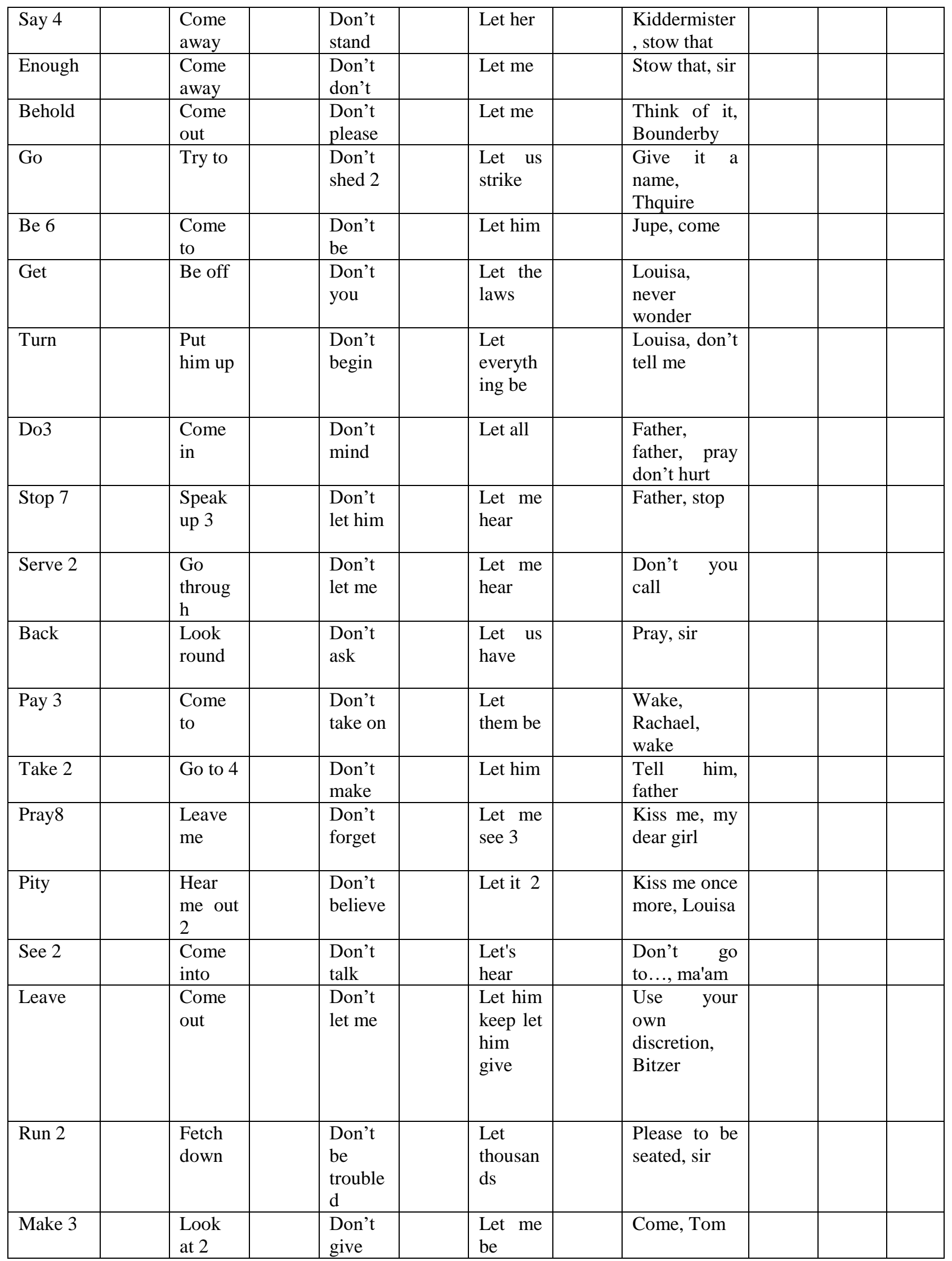


Website : www.uoajournal.com

E-mail : info@uoajournal.com

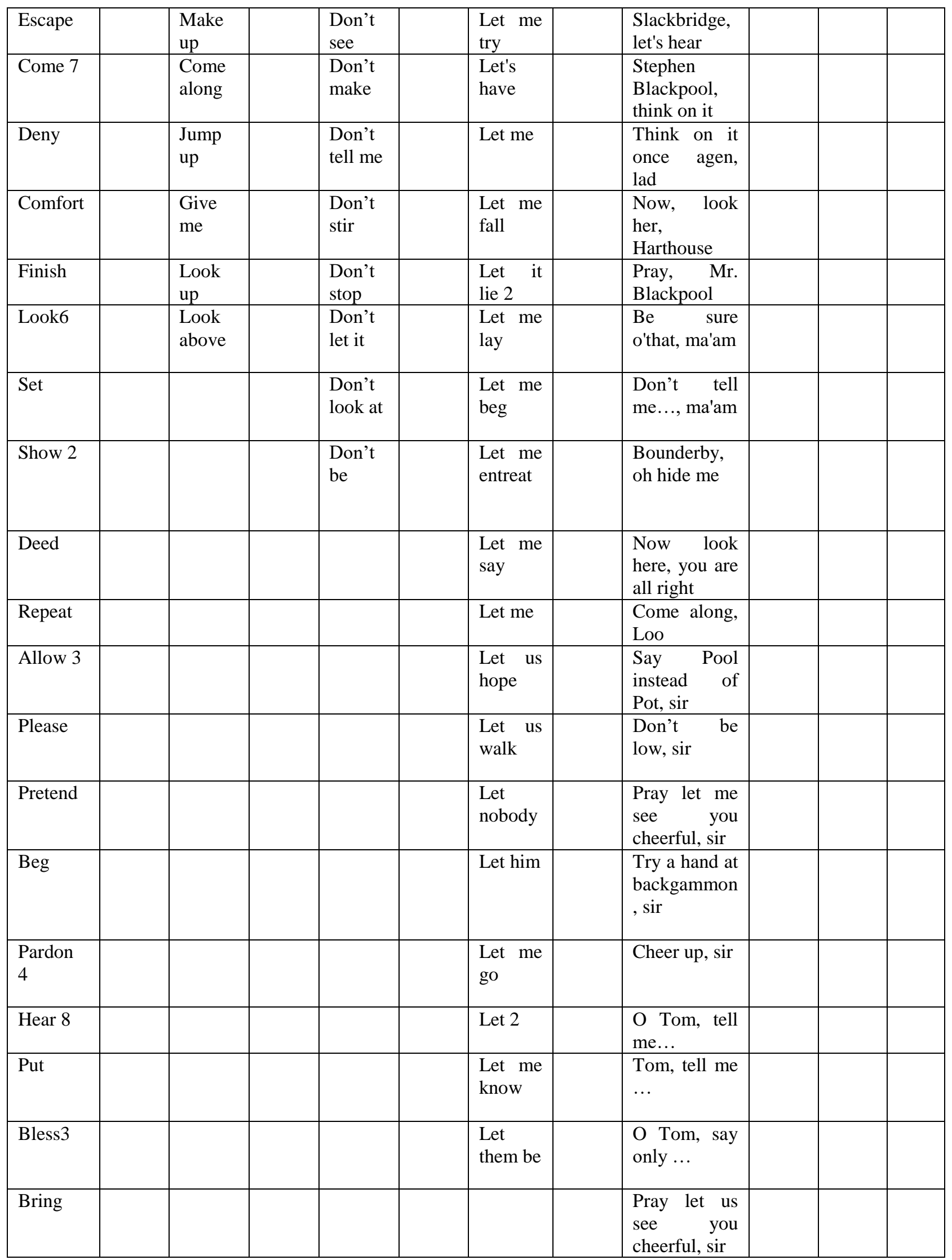


Website : www.uoajournal.com

E-mail : info@uoajournal.com

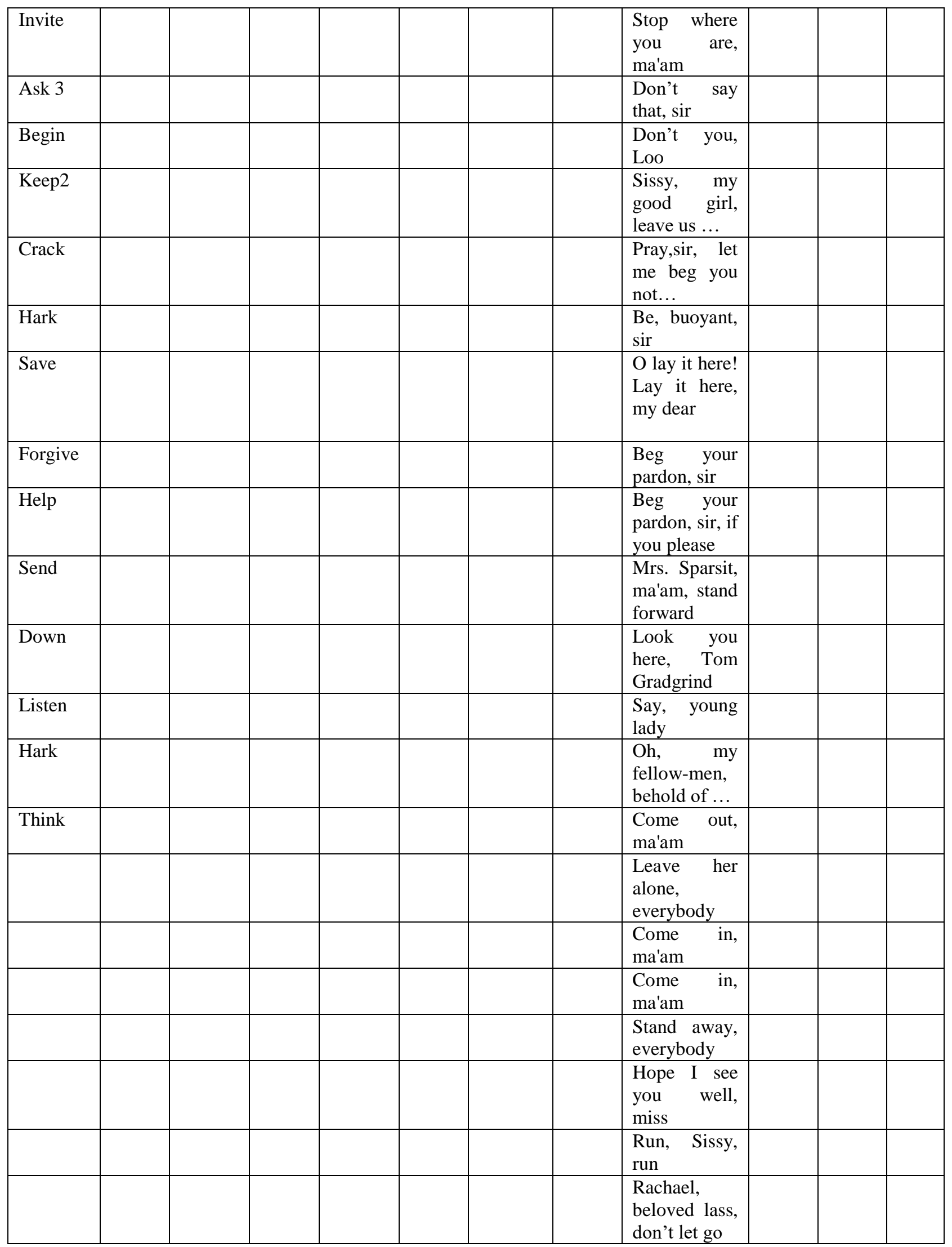




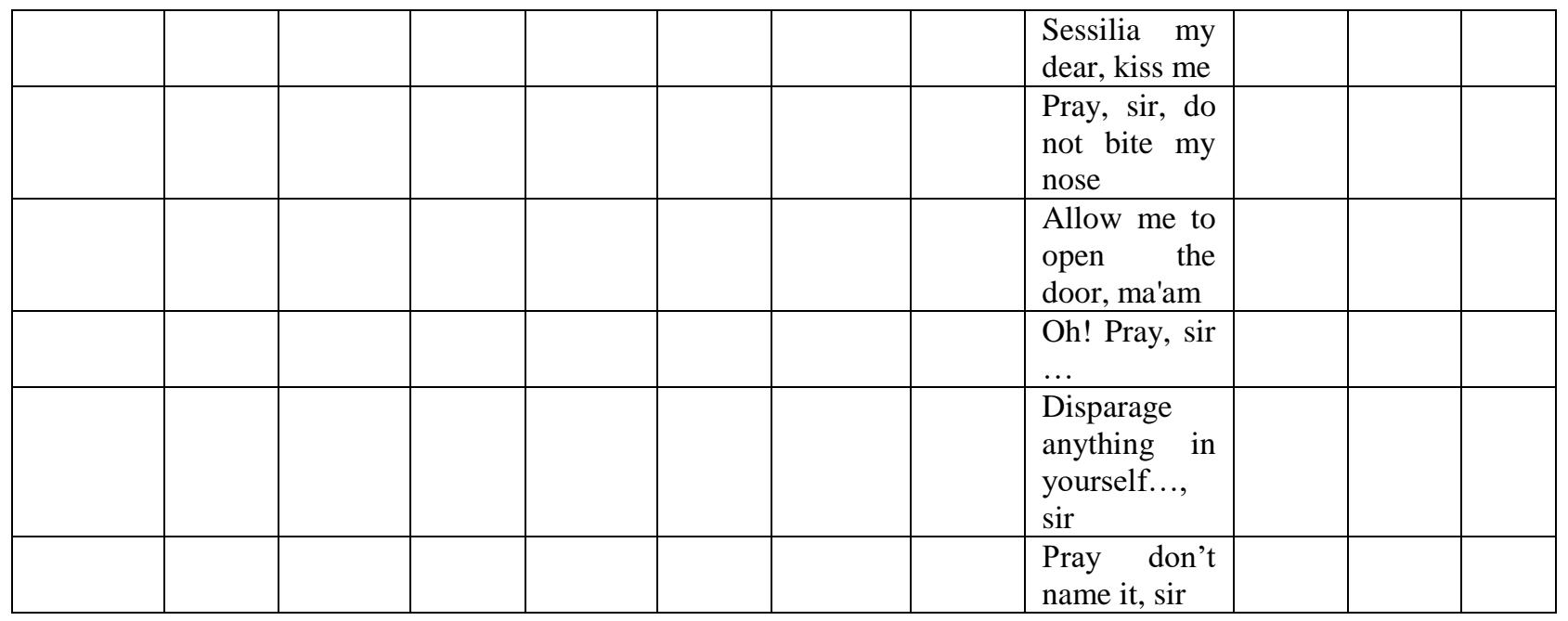

\section{7-2. Analysis of the Imperative functions}

In analyzing the functions of the imperative utterances, it is noticed that orders are highly used more than the other functions. In the following table the rates of the functions of the imperatives of Hard Times are illustrated.

Table (4): Frequency and Rate of Functions of Imperatives in Data

\begin{tabular}{|l|l|l|}
\hline Function of Imperative & Frequency & Rate \\
\hline Order/command & 92 & $27.058 \%$ \\
\hline Warning & 51 & $15 \%$ \\
\hline Suggestion & 49 & $14.411 \%$ \\
\hline Drawing attention & 32 & $9.411 \%$ \\
\hline Request & 25 & $7.35 \%$ \\
\hline Instruction & 19 & $5.58 \%$ \\
\hline Beseeching & 13 & $3.82 \%$ \\
\hline Invitation/offer & 10 & $2.94 \%$ \\
\hline Advice & 9 & $2.64 \%$ \\
\hline Threat & 5 & $1.47 \%$ \\
\hline Inquiry & 3 & $0.882 \%$ \\
\hline Expressing rudeness & 0 & 0 \\
\hline
\end{tabular}

As can be seen, the orders are the highest. Then the warning followed the orders in getting the second rank. The other functions are comparatively used less than the orders or warnings.

The reason for the highest rate of orders in this novel maybe attributed to the nature of the general conversations among the characters of the novel. Many of the conversations take place between the members of the of the high- class such as Mr. Gradgrind who was a wealthy retired merchant. He believes in the philosophy of rationalism and self- interest. He gives his orders to the low-class people such as Sissy Jupe who was kind and imaginative girl. Generally, orders which are said directly and impolitely, are commonly used as in the following examples: 
57-Describe your father as a horse breaker.

58-Call yourself Cecilia.

59-Stop a bit.

60-There! Get out, get out.

Mr. Gradgrind is asking Bitzer to give his definition about the horse by using a declarative sentence. It gives the function of order according to the situation, as in:

-'Bitzer, your definition of a horse'

Warnings are also commonly used. It occurs in the second positions. The speaker here warns the addressee to do something, as in the following examples:

61-Don't call yourself Sissy!

62-Be sure you don't make any mistake and don't forget.

Suggestions are expressed by using 'let's' structure as in:

63-Let's hear the man himself.

The negative imperative with 'let' take two forms either 'let's not' or 'don't let's', as in:

64-Don't let him come up till I have got away.

'Me' is used after let when the speaker talks with himself about what to do, as in:

65-Let me go away before I break my hearts.

We can also refer to another person other than the speaker and the addressee, for example:

\section{6-Let them be.}

There is an important point that to be highlighted is that the form does not necessarily conform with the function. There are many declarative sentences that express imperative functions such as:

67-Father, hush! She has come back.

Here, Mr. Sleary is talking with Mr. Gradgrind about Sissy and suddenly Sissy comes so Sleary's daughter tells his father to stop talking. As if to say "don't talk or stop talking ". She used a declarative sentence to express an imperative function which is requesting, but here she didn't express it directly.

\section{8 -you shall do what is deferential and respectful, or you shall not come here.}

Here, Mr. Bounderby is talking with Mr. Gradgring and describing Mrs. Sparsit by using a declarative sentence as an imperative function to give him an advice to be a respectful or doesn't come to his house. 


\section{Drawing Attention:}

69-Look at them again, look at them well.

70-see his sister here

71-now, hear what I have come to say.

\section{Request:}

72-tell him, father, as soon as you please

73-Allow me to open the door, ma'am.

74-say, young lady, if you please

\section{Instruction:}

75-come along to the coach and jump up behind.

76-walk in and they'll draw it here.

\section{Beseeching:}

77-no, don't, please, don't let me see them setting by the bed.

78-forgive me, pity me, help me and let me lay this head of mine upon a loving heart.

\section{Invitation:}

79-now, Jupe, if you are quite determined, come!

80-comfort yourself!

81-come to my poor place, missus and take a cup of tea.

\section{Advice:}

82-try to sleep in the chair, while I watch.

83-never fear, good people of anxious turn of mind.

84-Go and be somethigological directly.

Threat:

85-come out!

86-now, speak up!

87-come away from the bed!

\section{Inquiry:}

88-say what they are!

89-pray never speak to me!

Expressing Rudeness, this type of the function of the imperative is not used because the function of the ordering is highly used by the members who has the authority. Many declarative sentences are used in this novel to express different functions, for example:

90-please to turn your humble eye in my direction.

In this sentence, Mr. Bounderby was talking with Mrs. Sparsit about his wife then she asked him to not to look at her by using a polite word(please). This word is used to express a polite request. 
Also this example:

\section{1-if you please, I will leave a message for him with you.}

Another form of declarative sentences is used. For example, in the following sentences, we notice that the characters use the word (hush) to express the meaning of warning it means (don't speak) as in:

\section{2-Hush! That is enough.}

93-Hush! I hear the bells.

In the first sentence, Mr. Gradgrind was warning Mr. Bounderby not to talk or saying any word even not breathe. While in the second sentence, when Stephen was suffered from a dreadful night, he asked Rachael if he was wake in or dream in then suddenly he warned her not to speak, because he heard the bells.

Also some of the interrogative sentences in the novel express different imperative functions. Understanding these functions depends on finding the intended meaning of the utterances and on the context. By these two elements, the reader can detect the implicit meaning of the utterances. The researchers looked not only for direct imperatives, but also for the indirect ones depending on studying the events of the novel and sometimes on the descriptions given by the writer as in the following examples:

\section{4-will you allow me to ask you if it's always as black as this?}

Here the stranger is not asking a question to Mrs. Sparsit, but he is supposed to be requesting indirectly.

Directives such as commands, orders, requests and suggestions are those kinds of speech acts that the speakers use to get someone else to do something. They express what the speaker wants.

95-say only yes and I shall understand you.

96-now, stop a bit!

97-wake, Rachael, wake!

The basic functions of all the utterances (get out...) in the following examples are orders. They represent direct speech acts. These phrasal verbs often occur as directives. Such as:

98-there, get out, get out!

99-speak up like a man!

100-stand away, everybody!

The structure of (don't) be +adjective is used in imperatives to avoid doing something that might be considered wrong or bad for the speaker. (Be/don't be) describe the adjective or the behavior that the addressee should not do.

\section{1-don't be hard upon it.} 102-don't be troubled.

Here, Louisa and her mother were talking and her mother said something about Louisa's father so Louisa asked her mother not to be afraid. 
A special type of the imperative clauses is found with the verb Let. In some of the conversations of this novel, let is used with the first person plural pronoun (us) which is usually contracted to (let's).

\section{3-let us hope that tomorrow will bring something better. 104-let's hear the man himself}

Let's or let us can be used by the speaker to make suggestions or to give orders. This matter depends so much on the nature of the relation between the interlocutors. In addition, the context usually plays an important role in determining the function of the used imperative.

Vocatives are another kind of the imperative structures used in the conversations of the novel. The imperative does not usually have a subject, but a noun that could be used to make it clear to whom we are speaking. Vocatives can be freely placed either at the beginning or at the end of the clause as the following example:

105-tell him, father, as soon as you please

106-wake, Rachael, wake

107-Slackbridge, let's hear the man himself.

In the first two sentences, (father and Slackbridge) are addressed to emphasize the order. While the third sentence emphasizes the suggestion.

Some imperatives are followed by 'and' and another imperative. This structure is called double imperatives.

108-come in and speak up!

109-go and be somethiogological directly.

\section{Result and Discussions}

The study has come up with the following results:

1- The base of the verbs as come, ask, hear etc. are the most common forms of imperatives used by the characters. They represent $42.058 \%$ of the corpus. This kind of verbs express direct command and direct speech act to ask the hearer to perform the action.

2- There is a great tendency for the characters to use the vocative which is $21.470 \%$ of the total imperatives. This form is used in the characters' conversations for the purpose of monitoring the actions. The names of the characters are uttered by the characters at the beginning or at the end of the sentences to indicate emphatic threat or anger or sometimes to express respect.

3- The imperative structure let achieved the third position. Its rate is $14.705 \%$. Let has more than one communicative functions in this novel to express the intended meaning of the speaker. sometimes it is used to make suggestion or for begging and beseeching.

4- The frequent use of the phrasal verbs like speak up, get out, walk in is $11.47 \%$ of the total number of the imperatives in this novel. This type of command is used to convey anger, aggression, or irritation of the speaker towards the hearer.

5- Don't the base form of the verb is $10.29 \%$ in the corpus. The obvious function of this structure is to give orders, warnings, threats and to urge the hearer to follow the speaker instructions.

6- Generally, imperative + Tag question is not used in this novel. 
7- 7-Concerning the functions of the imperatives of the novel, it is noticed that orders' rate is higher than the rates of the other imperative functions, and this is due to the nature of the events and the character of the novel. Warning is the second.

8- There are different functions attributed to the imperative utterances such as (invitation, advice, inquiry, beseeching, warning, threat).

9- Many imperative functions are not reflected in imperative forms. That means functions don't necessarily conform to forms.

\section{Conclusions}

After analyzing all of the imperative utterances of the novel Hard Times, the researcher has reached to the following conclusions:

1- Imperative utterances are not necessarily reflected in imperative sentences. Many of the imperatives are expressed in declaratives or interrogatives

2- Many of the imperative utterances function not as commands or orders. Different speech acts are attributed to the imperatives such as requesting, begging, beseeching, beckoning, advising, warning, threatening, etc.

3- Because of the nature of the events of the novel and the characters, it is noticed that direct orders are commonly used than indirect ones because the later are politer than the direct. Most of the imperative utterances of the novel are used among the members of the high- class. So the language reflects the nature of the authority.

4- It is remarked that many of the imperatives mention the name of the person(s) or an attribution of it at the end of the utterance. This type of the imperatives softens or mitigates the orders as for example " kiss me, my dear". Nevertheless, there are cases when mentioning the name at the end is used to emphasize or strengthen the force of the orders such as " cheer up, sir".

5- It has been noticed that some imperatives are preceded by interjections which reveal the illocutionary acts of imperatives, for example: "O, Tom, say only" - "O, Tom, tell me".

6- It is noticed that there is a repetition of the imperative verbs in the same sentence. This structure used by the speaker who is nervous and sometimes this structure is used for emphasizing the imperative function. For example, "Give me a pen, give me a pen"- "get out, get out".

\section{Bibliography}

Alexander, J. (1997) Longman English Grammar. London: Longman

Bach, Kent and Robert, Harnish (1979) Linguistic communication and Speech Act, MA: MIT press

Biber, D.; Johnson, S.; Leech, G; Conrad, S. and Finegan, E.(1999) Longman Grammar of Spoken and Written English. London: Longman

Buscemi, S.; Nicolai, A.; Strugala, R.The Basics(2004) : A Rhetoric and Handbook 4th.ed.Higher Education. Mc. Hill 
Crystal, J (1991). A Dictionary of Linguistics and Phonetics.3rd ed. Oxford: Blackwell Publisher LTD

.......... (2004). A Dictionary of Linguistics and Phonetics. 5th. ed. Oxford: Blackwell Publisher LTD

Eastwood, J. (2005). Oxford Learner's Grammar. Oxford University Press

Levisohn, S. (1983). Pragmatics. Cambridge: Cambridge University Press

Mey , J ( 1993) . Pragmatics.: An Introduction. Oxford: Oxford Blackwell

Murphy.R. and Smalzer. W. (2002). Basic grammar in use. 2nd ed. Cambridge: Cambridge University Press

Praniniskas, J. (1975). Rapid Review of English Grammar. London: Prentice Hall. Inc

Quirk, R. Greenbaum, S.Leech, G. and Svartvik, J. (1985).A Comprehensive Grammar of English Language. London: London Croup Limited.

Radford, A.(2004). English Syntax: An Introduction. Cambridge: Cambridge University press

Searle, J (1969). Speech Act: An Essay in the Philosophy of Language .Cambridge: Cambridge University Press.

Swan, J. (2005). Practical English Usage. Oxford: Oxford University Press.

Wales, K. (1989). A Dictionary of Stylistics. London: Longman. 


\section{تر اكيب ووظائف الصيغ الأمرية في رواية الأوقات العصيبة للكاتب جارلس دكنس

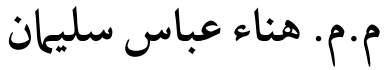 \\ قسم اللغة الانكليزية، كلية الآداب، جامعة الأنبار، العراق \\ hanaahanaa133@gmail.com}

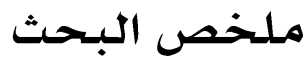

تعتزم هذه الدراسة على تسليط الضوء على مختلف اشكال ووظائف الجمل الأمرية في رواية الاوقات العصيبة ـ هذه الرواية متوفرة لتحقيق غرض الدراسة. واحدة من اغلب السمات المميزة هي الاستخدام المفرط للتراكيب الامرية. تظهرنتائج الدراسة ان الجمل الامرية شاع استخدامها بين شخصيات الرواية. تهدف هذه الدراسة لتحليل الصيغ الامرية المستخدمة في الرواية وتوضيح اشكالها ووظائفها المتعددة طبقا لنموذج الكسندر في عام 199 الذي سوف يُعتمد بتحليل البيانات من اجل تحقيق غرض الدراسة. سوف يتم ذكر نسب وتكرار كل نوع من انواع الامر في جداول من اجل توضيح كم عدد المرات المستخدمة لكل نوع اكثر من النوع الاخر مثل اسلوب الاقتراح، الطلب، الخ. نموذج الكسندر عام ( 1997 ) سيعتمد في تحليل العينات وهذه العينات تجمع من رواية الاوقات العصيبة. يؤمل من هذه الدراسة ان تكون ذات فائدة للأشخاص الذين يدرسون اللغة الانجليزية كلغة اجنبية واولئك الذين يستمتعون بدراسة اللغة الانجليزية.

الكلمات المفتاحية: الصيغ الأمرية، التكرار، الاستخدامات، التراكيب.

Crossref doi) https://doi.org/10.51345/.v31i2.322.g184 